\title{
Consequences of increasing or decreasing plasma FSH concentrations during the preovulatory period in Romney ewes
}

\author{
K. M. Henderson, L. C. Savage, R. L. Ellen, K. Ball and K. P. McNatty \\ Wallaceville Animal Research Centre, MAFTech, Ministry of Agriculture and Fisheries, \\ Private Bag, Upper Hutt, New Zealand
}

\begin{abstract}
Summary. Romney ewes were infused with ovine FSH (NIADDK-oFSH-16) for $48 \mathrm{~h}$ from the initiation of luteolysis with cloprostenol. Doses of 2.5 or $5 \mu \mathrm{g} / \mathrm{h}$ which partly or completely prevented the normal preovulatory decline in plasma FSH concentrations caused a significant increase in mean ovulation rates. Ovulation rates were not increased significantly if the FSH $(5 \mu \mathrm{g} / \mathrm{h})$ was infused for only $20 \mathrm{~h}$ starting from the initiation of luteolysis or $24 \mathrm{~h}$ later. Infusion of a less potent and relatively impure preparation of FSH (i.e. FSH-P) at $0.5 \mathrm{mg} / \mathrm{h}$ for $48 \mathrm{~h}$ after cloprostenol treatment also increased the mean ovulation rate significantly. However, if the FSH-P was given for only the first $24 \mathrm{~h}$, or if the start of the infusion was delayed for more than $12 \mathrm{~h}$, mean ovulation rates were not increased significantly. Infusion of LH (NIADDK-oLH-25, $5 \mu \mathrm{g} / \mathrm{h}$ ) for $48 \mathrm{~h}$ from the initiation of luteolysis decreased the mean ovulation rate significantly.

Administration of bovine follicular fluid to suppress plasma FSH concentrations below normal during the first $24 \mathrm{~h}$ after cloprostenol injection did not delay oestrus. However, oestrus was delayed by $\sim 2$ days if plasma FSH concentrations were reduced by bovine follicular fluid $24 \mathrm{~h}$ after the initiation of luteolysis.

As ovulation rate increased, the mean weight of individual corpora lutea of each ewe decreased. In ewes with a single ovulation, most corpora lutea weighed $>600 \mathrm{mg}$, but as the ovulation rate increased the proportion of corpora lutea present weighing $<400 \mathrm{mg}$ rose steadily. The mean concentrations of luteal tissue progesterone were not influenced significantly by ovulation rate.
\end{abstract}

Keywords: sheep; ovulation rate; FSH; follicular fluid

\section{Introduction}

In sheep, as in other species, adequate exposure to the pituitary gonadotrophins, follicle stimulating hormone (FSH) and luteinizing hormone ( $\mathrm{LH})$ is essential for follicles to mature and ovulate. After the onset of luteolysis, plasma concentrations of LH rise progressively as pituitary LH output is released from suppression by luteal progesterone. In contrast, plasma concentrations of FSH fall progressively due to the negative feedback effects on pituitary FSH production of the increasing amounts of oestradiol-17 (and possibly inhibin) secreted by the developing follicle(s) (Miller et al., 1981; Baird, 1983). This decline in plasma FSH concentrations persists until positive steroidal feedback elicits the preovulatory surge of gonadotrophins. Despite the falling plasma FSH concentrations during the preovulatory period, sustained follicular development still requires some $\mathrm{FSH}$, because reducing plasma FSH concentrations even further by administration of bovine follicular fluid (a rich source of inhibin) prevents follicles from attaining preovulatory maturity (Henderson et al., 1986). 
As follicle size increases, the sensitivity of sheep granulosa cells to FSH increases (Henderson et al., 1985, 1987). This may be important in ensuring that final maturation of follicles can occur in the face of declining plasma FSH concentrations during the preovulatory period. The increasing sensitivity to FSH of granulosa cells in large developing follicles probably protects them from the deleterious effects of low plasma FSH concentrations. Follicles less sensitive to FSH are likely to undergo atresia due to lack of FSH. By this reasoning, one may argue that additional follicles could be induced to reach ovulatory maturity by raising plasma concentrations of FSH during the preovulatory period, thereby increasing follicular exposure to FSH. This possibility was examined in the present study. Highly purified ovine FSH (NIADDK-oFSH-16) was infused to raise plasma FSH concentrations, while administration of bovine follicular fluid was used specifically to suppress plasma FSH concentrations (McNeilly, 1985; Henderson et al., 1986). For comparative purposes, the effects of infusion of FSH-P were also studied. FSH-P is commonly used to superovulate cows and goats, and less frequently sheep (Armstrong \& Evans, 1983; Monniaux et al., 1983). However, compared to NIADDK-oFSH-16, it is a relatively impure FSH preparation, and generally has more LH than FSH activity (Monniaux et al., 1983; Lindsell et al., 1986).

\section{Materials and Methods}

Gonadotrophins. Ovine FSH (NIADDK-oFSH-16, FSH activity $20 \times$ NIH-FSH-S1 U/mg, LH activity $0.04 \times$ NIHLH-S1 U/mg) and ovine LH (NIADDK-oLH-25; LH activity $2.3 \times$ NIH-LH-S1 U/mg, FSH contamination $<0.5 \%$ by weight) were provided by the National Hormone and Pituitary Program, National Institute of Diabetes and Digestive and Kidney Diseases, Bethesda, Maryland, U.S.A. FSH-P was obtained from Burns-Biotec Laboratories Inc., Omaha, Nebraska, U.S.A. Solutions of these gonadotrophins were prepared in saline $(0.9 \% \mathrm{NaCl} w / \mathrm{v})$ containing $0.2 \%$ ovine serum albumin immediately before their infusion into sheep.

Follicular fluid. A single batch of bovine follicular fluid (bFF) was used for the experiments in this study. Ovaries were collected from cows slaughtered at a local abattoir. Antral follicles on the surface of the ovaries were punctured with a 20-gauge needle, and the bFF aspirated under vacuum. Debris and red blood cells were removed from the pooled fluids by centrifugation at $1200 \mathrm{~g}$ for $15 \mathrm{~min}$ at $4^{\circ} \mathrm{C}$, and the supernatant was stored frozen at $-20^{\circ} \mathrm{C}$. Several collections of bFF were subsequently thawed, and steroids removed by treatment with dextran T-70 $(0 \cdot 1 \%$, Pharmacia Fine Chemicals AB, Uppsala, Sweden) coated charcoal (Norit A, 1\%, Fisher Scientific Co., Springfield, New Jersey, U.S.A.) as described previously (Henderson et al., 1986). The bFF was then stored at $-20^{\circ} \mathrm{C}$ until needed.

Sheep and their treatments. Parous New Zealand Romney ewes (aged 2.5-3.5 years, and weighing 50-60 kg) were used. These flock ewes were grazed on pasture and run with a vasectomized ram fitted with a marking harness. The ewes were examined daily for signs of oestrus.

Ewes between Days 8 and 11 of the oestrous cycle (Day $0=$ day of oestrus) were penned indoors. Those to be treated with $\mathrm{bFF}$ were fitted with one intrajugular cannula, for blood sampling. Those to receive gonadotrophins were fitted with two contralateral intrajugular cannulae, one for collecting blood samples and the other for infusing gonadotrophins. The next day luteolysis was initiated with an intramuscular (i.m.) injection of cloprostenol (125 $\mu \mathrm{g}$, Coopers Animal Health Ltd, Upper Hutt, New Zealand). Infusions of FSH, FSH-P, LH or vehicle alone began immediately thereafter. The solutions were delivered by an infusion pump adjusted to deliver $1 \mathrm{ml}$ of solution in 1 minute, once per hour for up to $48 \mathrm{~h}$. The infusate reservoir was packed in ice. Ewes receiving bFF were injected intramuscularly with $5 \mathrm{ml} \mathrm{bFF}$ at selected times after receiving cloprostenol. Blood samples $(2-3 \mathrm{ml})$ were taken from all ewes at selected times before injection of cloprostenol, and at 4-h intervals thereafter for up to $72 \mathrm{~h}$. At the end of this period the cannulae were removed, and the ewes were injected intramuscularly with antibiotic ( $5 \mathrm{ml}$ Streptopen: Glaxo New Zealand Ltd, Palmerston North, New Zealand), and returned to pasture. Ewes which had received bFF, together with their controls, were bled daily for a further 12 days. A vasectomized ram fitted with a marking harness was present with these sheep at all times, and the ewes were examined at least twice daily for signs of oestrus.

At 13 days after receiving cloprostenol, the ewes which had been subjected to infusion were slaughtered and their ovaries removed. The number of ovulations (ovulation rate) was determined by counting the number of corpora lutea present.

All blood samples were centrifuged at $1200 \mathrm{~g}$ for $15 \mathrm{~min}$ at $4^{\circ} \mathrm{C}$. The plasma was removed and stored frozen $\left(-20^{\circ} \mathrm{C}\right)$ until assayed for $\mathrm{FSH}, \mathrm{LH}$ and progesterone by radioimmunoassay.

Luteal tisue. Corpora lutea were dissected from the ovaries, trimmed free of adherent connective tissue, and weighed individually. Each corpus luteum was homogenized in $10 \mathrm{ml}$ chloroform:methanol $(2: 1, \mathrm{v} / \mathrm{v})$ and left to stand overnight at room temperature. The chloroform:methanol was then removed and stored at $-20^{\circ} \mathrm{C}$ until assayed for progesterone. A single homogenization in $10 \mathrm{ml}$ chloroform:methanol was found to be sufficient to extract $>99 \%$ 
of luteal progesterone, as assessed by the additional amount of progesterone extracted following a second homogenization in a further $10 \mathrm{ml}$ of extractant.

Radioimmunoassays. Plasma concentrations of FSH were measured using a double-antibody sheep FSH radioimmunoassay kit and procedures provided by the National Hormone and Pituitary Program, NIADDK, Bethesda, Maryland, U.S.A. The FSH reference preparation was NIAMDD-oFSH-RP-1 and the iodinated tracer was NIAMDD-oFSH-I-1. The FSH antiserum (rabbit) was NIAMDD-anti-oFSH-1. The sensitivity of the assay was $0 \cdot 05-0.1 \mathrm{ng}$ per assay tube $(0 \cdot 2-0.4 \mathrm{ng} / \mathrm{ml}$ plasma $)$ and the intra- and inter-assay coefficients of variation were $<10 \%$. Plasma concentrations of LH were measured by radioimmunoassay as described previously (McNatty et al., 1981), using an antibody raised in a rabbit against NIH-LH-S11. The LH antiserum exhibited low cross-reactions with other sheep pituitary hormones: prolactin (NIH-P-S12) $0.09 \%$; thyroid-stimulating hormone (NIH-TSH-S8) 2.4\%; growth hormone (NIH-GH-S11) $0 \cdot 4 \%$; FSH (NIH-FSH-S10) $0 \cdot 4 \%$. The pituitary LH preparation for both the standard and the iodinated tracer was NIH-LH-SII. The sensitivity of the assay was $0.04 \mathrm{ng}$ per assay tube $(0.2 \mathrm{ng} / \mathrm{ml}$ plasma), and the intra- and inter-assay coefficients of variation were $7 \%$ and $12 \%$ respectively. Progesterone was extracted from plasma with petroleum ether. The extraction efficiency was monitored by the addition of tritiated progesterone, and the mean recovery was $82 \%$. Aliquants of the organic extracts of plasma and luteal tissue were evaporated under a stream of nitrogen, and reconstituted in 0.1 M-phosphate buffered saline $(\mathrm{pH} 7)$ containing $0.1 \%$ gelatin and $0.1 \%$ sodium azide. Progesterone was measured in these aqueous samples by a specific radioimmunoassay described previously (McNatty et al., 1981). Steroids cross-reacting with the progesterone antiserum were $11 \alpha$-hydroxyprogesterone $(120 \%)$, 11 $\beta$-hydroxyprogesterone $(25 \%)$, 20 -dihydroprogesterone $(3.5 \%)$ and androstenedione $(0.4 \%)$. The limit of sensitivity of the assay (per tube) was $25 \mathrm{pg}(125 \mathrm{pg} / \mathrm{ml})$, and the intra- and inter-assay coefficients of variation were $<10 \%$.

Statistics. The data were analysed statistically using analysis of variance in conjunction with Newman-Keuls multiple range test, or Student's $t$ test as appropriate. When heterogeneity of variance was indicated by Bartlett's test, the variances were equalized by transforming the data to logarithms $(\ln (\mathrm{x}+1))$. In these instances the data have been presented as geometric means together with $95 \%$ confidence limits (Tables 1-3, Fig. 4). The level of significance was set at $P<0.05$.

\section{Results}

\section{Effects of infusion of ovine FSH (NIADDK-oFSH-16) and LH (NIADDK-oLH-25)}

Figure 1 shows the effect on plasma FSH concentrations of infusion of FSH $(0,2.5$ and $5 \mu \mathrm{g} / \mathrm{h})$ for $48 \mathrm{~h}$ from the initiation of luteolysis. Blood samples were taken $24,16,8$ and $0 \mathrm{~h}$ before injection of cloprostenol, and at 4 -h intervals thereafter for $48 \mathrm{~h}$. From 8 to $40 \mathrm{~h}$ after injection of cloprostenol, mean plasma concentrations of FSH were significantly higher in ewes receiving $5 \mu \mathrm{g} \mathrm{FSH} / \mathrm{h}$ than in ewes receiving 0 (control ewes) or $2.5 \mu \mathrm{g} \mathrm{FSH} / \mathrm{h}(P<0.01)$. In ewes receiving $2.5 \mu \mathrm{g} \mathrm{FSH} / \mathrm{h}$, mean plasma concentrations of FSH were significantly higher than those of control ewes from 16 to $36 \mathrm{~h}$ after injection of cloprostenol $(P<0.05)$. Infusion of 2.5 and $5 \mu \mathrm{g} \mathrm{FSH} / \mathrm{h}$ for the 48 -h period also caused a dose-dependent increase in mean ovulation rates (Table 1). Control ewes had ovulation rates of 1 or 2 . In ewes receiving $2.5 \mu \mathrm{g} \mathrm{FSH} / \mathrm{h}$, most ewes had ovulation rates of 2 or 3 , but no higher, whereas in ewes receiving $5 \mu \mathrm{g} \mathrm{FSH} / \mathrm{h}$ ovulation rates of $4,6,8,9$ and 14 were recorded in 5 ewes.

In contrast to the effects of $\mathrm{FSH}$, infusion of $\mathrm{LH}$ for the 48-h period resulted in a significant decrease in mean ovulation rate, relative to control ewes. Plasma LH concentrations were raised substantially during the infusion of $\mathrm{LH}$, relative to control ewes $(2.5 \pm 0.2$ vs $0.6 \pm 0.1 \mathrm{ng} \mathrm{LH} / \mathrm{ml}$, overall mean values \pm s.e.m. for 8 ewes/group, $P<0.001$ ). However, mean FSH concentrations did not differ significantly from those of the control ewes $(1 \cdot 0 \pm 0 \cdot 2$ vs $0 \cdot 9 \pm 0 \cdot 1 \mathrm{ng} \mathrm{FSH} / \mathrm{ml}$ for LH-infused and control ewes respectively, overall mean values \pm s.e.m. for 8 ewes/group, $P>0.05)$. Figure 2 shows the effect on plasma FSH concentrations of infusion of FSH $(5 \mu \mathrm{g} / \mathrm{h})$ for $20 \mathrm{~h}$ beginning from the start or $24 \mathrm{~h}$ after the start of luteolysis. Blood samples were taken 24,12 and $0 \mathrm{~h}$ before administration of cloprostenol and at 4-h intervals thereafter for $48 \mathrm{~h}$. In ewes receiving FSH from the start of luteolysis (Fig. 2a), the mean plasma FSH concentrations were significantly higher than in control ewes (infused with vehicle alone) from 8 to $20 \mathrm{~h}$ after injection of cloprostenol. In addition, in those FSH-infused ewes, the mean plasma FSH concentrations were only $\leqslant 1 \mathrm{ng} / \mathrm{ml}$ for a $12-\mathrm{h}$ period from 24 to $36 \mathrm{~h}$ after cloprostenol, whereas in control ewes mean values were $\leqslant 1 \mathrm{ng} / \mathrm{ml}$ for $28 \mathrm{~h}$ from 12 to $40 \mathrm{~h}$ after cloprostenol. In ewes infused with FSH for $20 \mathrm{~h}$, 


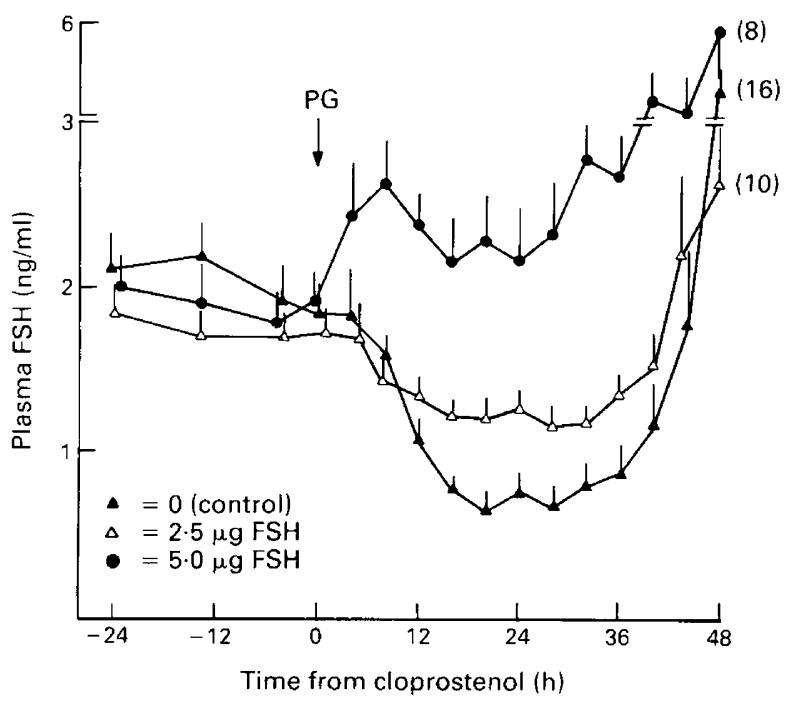

Fig. 1. Plasma FSH concentrations of ewes infused with $0,2.5$ or $5 \mu \mathrm{g}$ FSH (NIADDK-oFSH$16) / \mathrm{h}$ for $48 \mathrm{~h}$ from the start of luteolysis with cloprostenol (PG). Values are means of (N) ewes. Vertical lines show the s.e.m.

Table 1. Frequency of ovulation rates and mean ovulation rates after infusion of ovine FSH (NIADDK-oFSH-16) or LH (NIADDK$\mathrm{oLH}-25$ ) for $48 \mathrm{~h}$ from the start of luteolysis

\begin{tabular}{|c|c|c|c|c|c|c|}
\hline \multirow[b]{2}{*}{ Treatment } & \multicolumn{5}{|c|}{ Ovulation rate } & \multirow{2}{*}{$\begin{array}{c}\text { Geometric mean } \\
\text { ovulation rate } \\
(95 \% \text { confidence limits }\end{array}$} \\
\hline & 0 & 1 & 2 & 3 & $4-14$ & \\
\hline Vehicle alone & 0 & 10 & 6 & 0 & 0 & $1 \cdot 3(1 \cdot 1-1 \cdot 6)$ \\
\hline $2 \cdot 5 \mu \mathrm{g} \mathrm{FSH} / \mathrm{h}$ & 0 & 1 & 6 & 3 & 0 & $2 \cdot 1(1 \cdot 7-2 \cdot 7)$ \\
\hline $5.0 \mu \mathrm{g} \mathrm{FSH} / \mathrm{h}$ & 0 & 0 & 3 & 0 & 5 & $4.8(2.4-8.8)$ \\
\hline $5.0 \mu \mathrm{g} \mathrm{LH} / \mathrm{h}$ & 2 & 6 & 0 & 0 & 0 & $0.7(0.3-1.2)$ \\
\hline
\end{tabular}

Geometric mean values differ significantly between all groups, $P<0.05$.

starting $24 \mathrm{~h}$ after injection of cloprostenol (Fig. 2b), the mean plasma concentrations of FSH were only significantly higher than those in the control ewes in the blood sampling at $36 \mathrm{~h}$. However, mean plasma FSH concentrations rose above $1 \mathrm{ng} / \mathrm{ml}$ from $32 \mathrm{~h}$ after cloprostenol in the FSHinfused ewes, whereas in the control ewes mean FSH values did not rise consistently above $1 \mathrm{ng} / \mathrm{ml}$ until $40 \mathrm{~h}$ after cloprostenol. Infusion of FSH for these 20 -h periods did not significantly influence mean ovulation rates. In ewes infused with FSH for $20 \mathrm{~h}$ from the time of injection of cloprostenol, the mean ovulation rate was $1.6 \pm 0.2$ (s.e.m.), compared to $1.4 \pm 0.2$ for control ewes $(\mathrm{N}=8$, $P>0.05$ ). In ewes in which the start of the $20 \mathrm{~h}$ infusion was delayed until $24 \mathrm{~h}$ after injection of cloprostenol, the mean ovulation rate was $1.4 \pm 0.2$ and in the control ewes it was $1.5 \pm 0.2$ $(\mathrm{N}=8, P>0.05)$.

Infusion of FSH for the 20 -h periods or for $48 \mathrm{~h}$ had no significant effect on plasma progesterone concentrations, relative to control ewes. In all groups, mean plasma concentrations of progesterone were $\sim 2 \mathrm{ng} / \mathrm{ml}$ immediately before injection of cloprostenol. Mean values then fell to about $0.5 \mathrm{ng} / \mathrm{ml}$ within $24 \mathrm{~h}$ and remained at this level for the remainder of the 48 -h post-injection sampling period. 


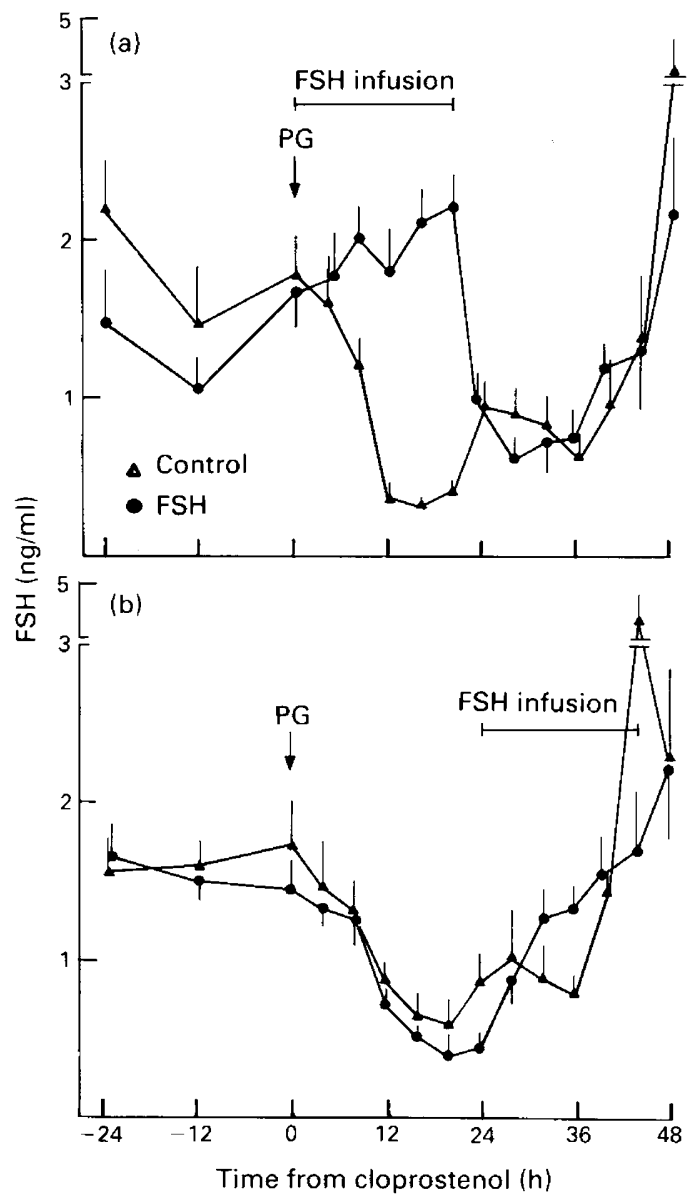

Fig. 2. Plasma FSH concentrations of ewes infused with $5 \mu \mathrm{g}$ NIADDK-oFSH-16/h for $20 \mathrm{~h}$ starting (a) at the time of cloprostenol injection (PG) and (b) $24 \mathrm{~h}$ after injection of cloprostenol. Values are means of 8 ewes with vertical lines showing the s.e.m.

\section{Reduction of plasma FSH concentrations with bFF}

A single intramuscular injection of $5 \mathrm{ml} b F F$ at the time of cloprostenol treatment caused a marked fall in mean plasma FSH concentrations (Fig. 3a). Within 8-12 h of injection, the mean FSH concentrations were significantly below the control values, but had risen to control values by $24 \mathrm{~h}$. A second intramuscular injection of $5 \mathrm{ml} \mathrm{bFF}, 12 \mathrm{~h}$ after the first, kept mean FSH concentrations significantly below control values for a further $28 \mathrm{~h}$. In ewes given the single injection of $\mathrm{bFF}$, the mean time to oestrus from injection of cloprostenol was $2.5 \pm 0.2$ (s.e.m.) days, which was not significantly different from that for control ewes $(2.3 \pm 0.2$ days, $\mathrm{N}=5, P>0.05)$. However, in ewes given 2 injections of $\mathrm{bFF}$, the mean time to oestrus was lengthened significantly to $4 \cdot 8 \pm 0 \cdot 4$ days $(P<0.05, \mathrm{~N}=5)$. Administration of 2 intramuscular injections of $5 \mathrm{ml} \mathrm{bFF} 24$ and $36 \mathrm{~h}$ after cloprostenol injection also caused a significant delay in the time to oestrus $(4 \cdot 2 \pm 0.5 v s 2.4 \pm 0 \cdot 1$ days, mean \pm s.e.m. for $\mathrm{N}=5, P<0 \cdot 01$ ). Plasma FSH concentrations did not differ between this group and its control group for the first $36 \mathrm{~h}$ after cloprostenol injection (Fig. 3b). Thereafter, the mean FSH concentrations in control ewes rose steadily while those in the bFF-treated ewes remained at basal values until $60 \mathrm{~h}$ after cloprostenol treatment. The increase in the time to oestrus 
after injection of $\mathrm{bFF}$, and the consequent delay in formation of new corpora lutea was also reflected in plasma progesterone concentrations. In all groups, mean plasma concentrations fell rapidly from $\sim 2$ to $0.5 \mathrm{ng} / \mathrm{ml}$ within $24 \mathrm{~h}$ of administration of cloprostenol. In control ewes and in ewes receiving a single injection of bFF at the time of cloprostenol administration, mean plasma concentrations of progesterone had risen above $1 \mathrm{ng} / \mathrm{ml}$ again, indicative of the formation of new corpora lutea, by 9 days after receiving cloprostenol. However, in ewes receiving bFF, 0 and $12 \mathrm{~h}$ or 24 and $36 \mathrm{~h}$ after cloprostenol, it was 10 and 11 days respectively after cloprostenol injection before mean plasma progesterone concentrations were again $>1 \mathrm{ng} / \mathrm{ml}$.

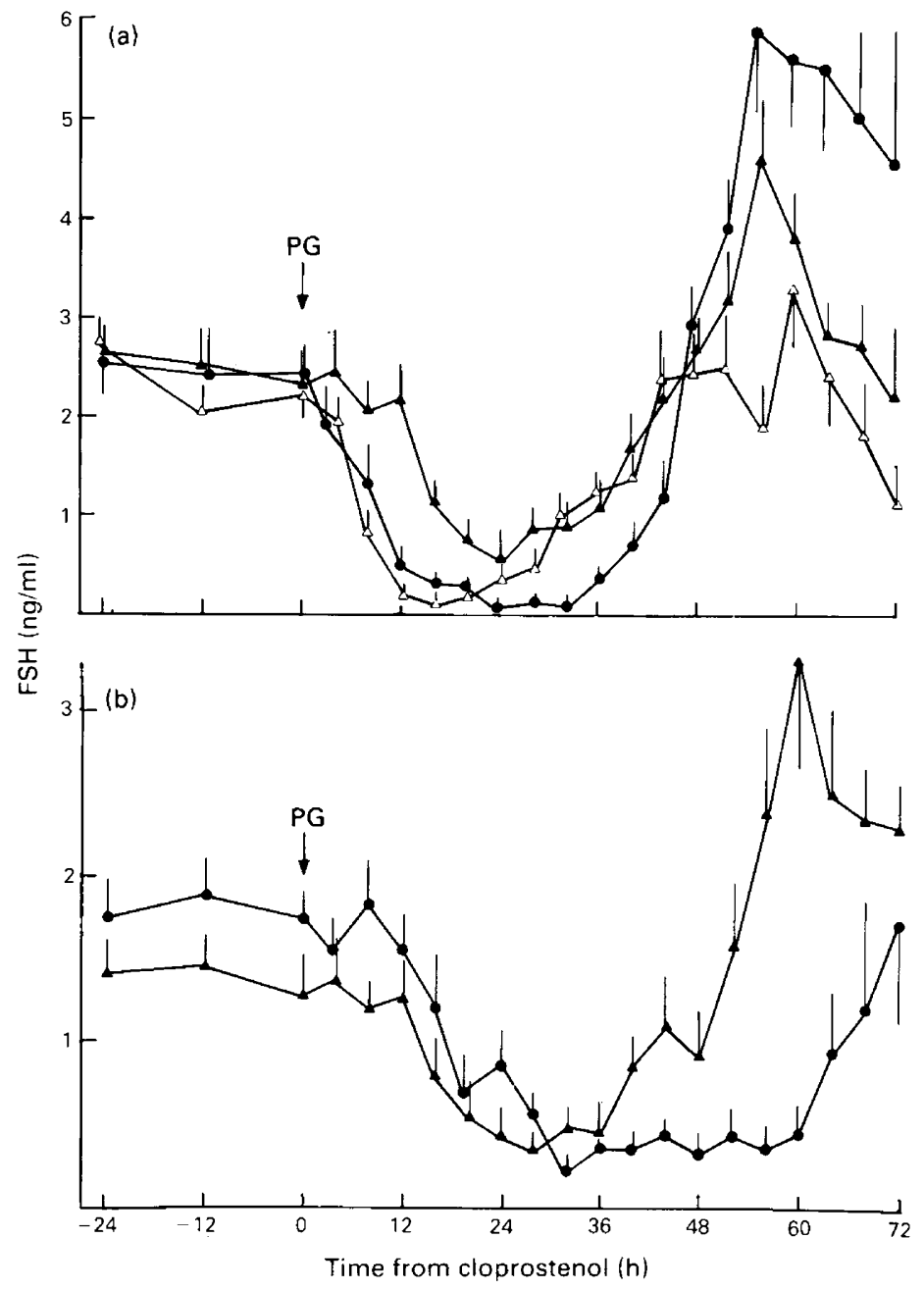

Fig. 3. Effect of administration of bovine follicular fluid on plasma FSH concentrations in sheep. Values are means of 5 ewes with vertical lines showing the s.e.m. (a) $\boldsymbol{\Delta}-\boldsymbol{\Delta}$ cloprostenol alone (controls); $\triangle-\triangle 5 \mathrm{ml} \mathrm{bFF} \mathrm{i.m.} \mathrm{at} \mathrm{time} \mathrm{of} \mathrm{cloprostenol} \mathrm{injection;} 5 \mathrm{ml}$ bFF i.m. 0 and $12 \mathrm{~h}$ after cloprostenol injection (PG). (b) $\mathbf{\Delta}-\mathbf{\Delta}$ cloprostenol alone (controls); $5 \mathrm{ml}$ bFF i.m. 24 and $36 \mathrm{~h}$ after cloprostenol injection (PG). 


\section{Effects of infusions of FSH-P}

Table 2 shows that infusion of FSH.P at $0.5 \mathrm{mg} / \mathrm{h}$ for $48 \mathrm{~h}$ from the start of luteolysis significantly increased the geometric mean ovulation rate, relative to control ewes (infused with vehicle alone). The mean ovulation rates were not increased significantly if this dose of FSH-P was infused for only the first $24 \mathrm{~h}$ (Table 2), or if the start of the infusion was delayed for more than $12 \mathrm{~h}$ after injection of cloprostenol (Fig. 4).

Table 2. Frequency of ovulation rates and mean ovulation rates (8 ewes/group) after infusion of FSH-P from the start of luteolysis

\begin{tabular}{|c|c|c|c|c|c|}
\hline \multirow[b]{2}{*}{ Dose of FSH-P } & \multicolumn{4}{|c|}{ Ovulation rate } & \multirow{2}{*}{$\begin{array}{c}\text { Geometric mean } \\
\text { ovulation rate } \\
(95 \% \text { confidence limits })\end{array}$} \\
\hline & 1 & 2 & 3 & $4-8$ & \\
\hline 0 & 5 & 3 & 0 & 0 & $1 \cdot 3^{a} \quad(1 \cdot 0-1 \cdot 8)$ \\
\hline $0.1 \mathrm{mg} / \mathrm{h}$ for $48 \mathrm{~h}$ & 2 & 2 & 0 & 4 & $3 \cdot 1^{a+b}(1 \cdot 5-5 \cdot 7)$ \\
\hline $0.5 \mathrm{mg} / \mathrm{h}$ for $48 \mathrm{~h}$ & 1 & 2 & 0 & 5 & $4 \cdot 3^{b} \quad(2 \cdot 2-7 \cdot 6)$ \\
\hline $0.5 \mathrm{mg} / \mathrm{h}$ for $24 \mathrm{~h}$ & 3 & 3 & 1 & 1 & $2 \cdot 0^{a \cdot b}(1 \cdot 1-3 \cdot 3)$ \\
\hline
\end{tabular}

Geometric mean values with different superscripts are significantly different $(P<0 \cdot 025)$.

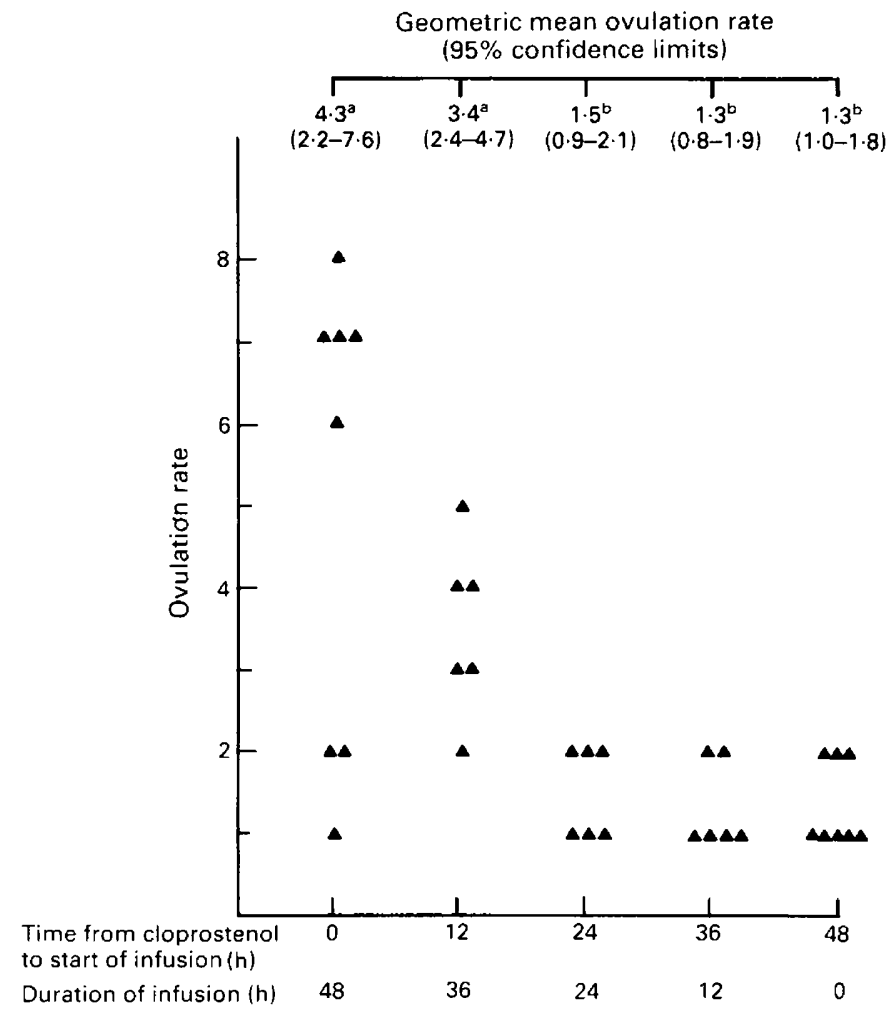

Fig. 4. Effect on ovulation rate ( $\Delta$ for individual ewes) of delaying the start of infusion of FSH-P $(0.5 \mathrm{mg} / \mathrm{h})$ after initiation of luteolysis with cloprostenol. Geometric mean ovulation rate values with different superscripts are significantly different $(P<0.025)$. 


\section{Corpus luteum weights and progesterone concentrations}

The corpus luteum data were grouped together irrespective of ewe treatment because, for any given ovulation rate, there was no significant effect of treatment on the weights or progesterone concentrations of the corpora lutea. As ovulation rate increased, the geometric mean weight of the individual corpora lutea per ewe fell significantly (Table 3). Examination of the individual corpus luteum weights showed that, when the ovulation rate was $1,94 \%$ of corpora lutea weighed $>600 \mathrm{mg}$. However, $\leqslant 30 \%$ of CL weighed $>600 \mathrm{mg}$ in ewes with ovulation rates $\geqslant 2$. As ovulation rate increased, the proportion of corpora lutea weighing $<400 \mathrm{mg}$ increased progressively. The geometric mean concentrations of luteal progesterone were not significantly influenced by ovulation rate.

Table 3. Influence of ovulation rate on the distribution of corpus luteum weights, geometric mean luteal weights, and geometric mean luteal progesterone concentrations

\begin{tabular}{|c|c|c|c|c|c|c|c|c|c|}
\hline \multirow[b]{2}{*}{$\begin{array}{l}\text { Ovulation } \\
\text { rate }\end{array}$} & \multicolumn{6}{|c|}{ Wt of corpora lutea (mg) } & \multirow{2}{*}{$\begin{array}{l}\text { Geometric mean } \\
\text { luteal wt }(\mathrm{mg}) \\
\text { per ewe } \\
\text { (95\% confidence } \\
\text { limits) }\end{array}$} & \multirow{2}{*}{$\begin{array}{l}\text { Geometric mean } \\
\text { luteal progesterone } \\
\text { conc. }(\mu \mathrm{g} / \mathrm{g}) \text { per ewe } \\
(95 \% \text { confidence } \\
\text { limits })\end{array}$} & \multirow{2}{*}{$\begin{array}{l}\text { No. of } \\
\text { ewes } \\
\text { (N) }\end{array}$} \\
\hline & $\begin{array}{l}100- \\
399\end{array}$ & $\begin{array}{c}400- \\
499\end{array}$ & $\begin{array}{c}500- \\
599\end{array}$ & $\begin{array}{c}600- \\
699\end{array}$ & $\begin{array}{l}700- \\
799\end{array}$ & $>800$ & & & \\
\hline I & 0 & 0 & 3 & 19 & 16 & 14 & $\begin{array}{c}722^{\mathrm{a}} \\
(694-752)\end{array}$ & $\begin{array}{c}7 \cdot 4 \\
(6 \cdot 7-8 \cdot 2)\end{array}$ & 52 \\
\hline 2 & 4 & 27 & 33 & 20 & 4 & 4 & $\begin{array}{c}549^{\mathrm{b}} \\
(526-573)\end{array}$ & $\begin{array}{c}7 \cdot 5 \\
(7 \cdot 0-8 \cdot 1)\end{array}$ & 46 \\
\hline 3 & 8 & 5 & 3 & 2 & 0 & 0 & $\begin{array}{c}435^{\mathfrak{c}} \\
(381-497)\end{array}$ & $\begin{array}{c}7 \cdot 7 \\
(6 \cdot 5 \cdot 9 \cdot 2)\end{array}$ & 6 \\
\hline $4,5,6$ & 28 & 12 & 5 & 0 & 0 & 0 & $\begin{array}{c}349^{\mathrm{d}} \\
(322-377)\end{array}$ & $\begin{array}{c}7 \cdot 1 \\
(6 \cdot 1-8 \cdot 3)\end{array}$ & 9 \\
\hline $7,8,9,14$ & 54 & 16 & 2 & 2 & 0 & 0 & $\begin{array}{c}339^{d} \\
(301-382)\end{array}$ & $\begin{array}{c}6 \cdot 6 \\
(5 \cdot 1-8 \cdot 5)\end{array}$ & 9 \\
\hline
\end{tabular}

The number of ewes with ovulation rates of $4,5,6,7,8,9$ and 14 were $4,1,4,5,2,1$ and 1 , respectively.

Geometric mean values with different superscripts in the same column are significantly different $(P<0.05)$.

\section{Discussion}

The present study demonstrates, for sheep, that relatively small changes in plasma FSH concentrations during the preovulatory period have a marked effect on follicular development and subsequent ovulation rate. Raising plasma FSH concentrations, and thereby increasing ovarian exposure to $\mathrm{FSH}$, enhances follicular development and increases ovulation rates. In contrast, decreasing plasma FSH concentrations below normal impairs follicular development, as indicated by a lengthened time to oestrus.

Partial or complete prevention of the normal preovulatory decline in plasma FSH concentrations (Fig. 1) was associated with a subsequent increase in mean ovulation rates (Table 1). This is consistent with the notion that the normally low preovulatory plasma FSH concentrations may restrict the number of follicles which can normally attain preovulatory maturity. Only those follicles in which the granulosa cells (the target cells for FSH action) have an increased sensitivity to FSH (Henderson et al., 1985, 1987) may be able to continue their development in the face of such low plasma FSH concentrations. By infusing FSH and thereby raising plasma FSH concentrations, additional follicles can be brought to ovulatory maturity and hence ovulation rates increased. In normal circumstances these additional follicles would probably have undergone atresia due to their 
relative insensitivity to FSH. Raising mean plasma FSH concentrations for $20 \mathrm{~h}$ but then letting the concentrations drop back to normal values again (Fig. 2a) did not result in an increase in the mean ovulation rate. Continual exposure to elevated plasma FSH concentrations therefore seems necessary to bring these additional follicles to preovulatory maturity. Similarly, commencing infusion of FSH $24 \mathrm{~h}$ after initiating luteolysis (Fig. 2b) also failed to increase the mean ovulation rate. Thus, follicles that had previously been exposed to low FSH concentrations, and so likely to be already undergoing atresia, could not be 'rescued' and brought to ovulatory maturity in synchrony with the presumptive preovulatory follicle(s). An increase in the frequency of double ovulations can be achieved by infusing FSH for a 24-h period in the $48 \mathrm{~h}$ before initiating luteolysis (McNatty et al., 1985). Presumably this treatment is advancing the maturation of a follicle (which would normally have undergone atresia), thereby allowing it to 'survive' the preovulatory fall in plasma FSH concentrations and attain ovulatory maturity.

In contrast to FSH, infusion of $\mathrm{LH}$ did not increase the mean ovulation rate (Table 1). During the preovulatory period, plasma LH concentrations are increasing (Baird, 1983). Presumably, therefore, it is the availability of $\mathrm{FSH}$, rather than $\mathrm{LH}$, which is the major factor which limits the number of follicles maturing to ovulation. However, it is still possible that the administration of LH together with FSH may allow more follicles to attain ovulatory maturity in synchrony than by giving FSH alone.

Specific suppression of preovulatory plasma FSH concentrations by administration of bFF has a deleterious effect on granulosa cell proliferation, follicular oestradiol-17 $\beta$ biosynthesis, and the development of cellular responsiveness to FSH and LH (Henderson et al., 1986). Consequently, oestrus is delayed until bFF treatment is stopped and preovulatory maturation is restored (Henderson et al., 1986). In the present study, bFF was used to reduce plasma FSH concentrations below normal at different times throughout the preovulatory period. If the normal fall in plasma FSH concentrations occurring after the initiation of luteolysis was accelerated (Fig. 3a), oestrus was not delayed, providing that plasma FSH concentrations returned to normal for the second $24 \mathrm{~h}$ period (Fig. 3a). However, if plasma FSH concentrations were suppressed for longer (Fig. 3a), or if bFF was given $24 \mathrm{~h}$ after the initiation of luteolysis (Fig. 3b), then oestrus was delayed. Adequate exposure to FSH therefore appears to be required for follicular development even during the final stages of maturation. This is consistent with the findings of Zeleznik \& Kubik (1986) for the monkey. It is unlikely that the lengthened time to oestrus, resulting from bFF treatment, was due to a direct action of bFF on the ovary, rather than as a consequence of reduced plasma FSH concentrations. Previous studies have shown that this effect of bFF treatment can be prevented by simultaneous treatment with FSH (McNeilly, 1985) or pregnant mares' serum gonadotrophin (Henderson et al., 1986).

Repeated injection of FSH-P, starting before the onset of luteolysis and continuing throughout the follicular period, have previously been found to increase ovulation rates in sheep (Wright $e t$ al., 1981; Armstrong \& Evans, 1983). Infusion of FSH-P for $48 \mathrm{~h}$ from the start of luteolysis also increased mean ovulation rate, although at a higher dosage than with the ovine FSH (Table 2). However, as with the ovine FSH, infusion of FSH-P for only the first $24 \mathrm{~h}$ also failed to increase the mean ovulation rate (Table 2). Similarly, if the start of the infusion was delayed for longer than $12 \mathrm{~h}$ after the initiation of luteolysis, ovulation rates $>2$ were not observed (Fig. 4). Interestingly, the mean ovulation rate of ewes infused for $48 \mathrm{~h}$ with $0.5 \mathrm{mg} \mathrm{FSH}-\mathrm{P} / \mathrm{h}(5.0 \pm 1.0)$ was similar to that obtained in Romney ewes given a similar total dosage as multiple injections over a 96-h period, starting $48 \mathrm{~h}$ before the removal of vaginal progestagen sponges (Armstrong \& Evans, 1983; K. P. McNatty, unpublished observations). Perhaps the development of devices whereby low amounts of FSH can be given continuously (e.g. by slow release) may provide a more efficient means of inducing superovulation than by the administration of FSH preparations as repeated injections.

As ovulation rate increased, the mean corpus luteum weight decreased (Table 3), suggesting that an increasing number of follicles were ovulating at a smaller size than usual. The actual growth (i.e. increase in size) of a follicle may be independent of its acquisition of characteristics associated 
with preovulatory maturity. Thus, raising plasma FSH concentrations above the normal threshold concentrations, thereby increasing ovarian exposure to FSH, may allow follicles to attain preovulatory maturity at a smaller size than normal. In highly prolific Booroola sheep, which naturally have high ovulation rates, mean corpus luteum weights are also inversely related to ovulation rate (McNatty et al., 1986). In this breed, the presence of a fecundity gene is thought to result in more follicles ovulating at smaller diameters as a consequence of increased ovarian exposure to FSH (McNatty et al., 1986, 1987).

We thank the National Institute of Arthritis, Diabetes and Digestive and Kidney Diseases, Bethesda, U.S.A., for providing the gonadotrophins and FSH radioimmunoassay reagents; $\mathrm{Mr}$ G. Aliprantis for assistance in obtaining ovaries from the Wellington Abattoir for collecting bFF, and the Wallaceville farm staff for supervision and care of the sheep at Wallaceville.

\section{References}

Armstrong, D.T. \& Evans, G. (1983) Factors influencing success of embryo transfer in sheep and goats. $J$. Reprod. Fert. 69, 31-42.

Baird, D.T. (1983) Factors regulating the growth of the preovulatory follicle in the sheep and human. $J$. Reprod. Fert. 69, 343-352.

Henderson, K.M., Kieboom, L.E., McNatty, K.P., Lun, S. \& Heath, D. (1985) Gonadotrophin-stimulated cyclic AMP production by granulosa cells from Booroola $\times$ Romney ewes with and without a fecundity gene. J. Reprod. Fert. 75, 111-120.

Henderson, K.M., Prisk, M.D., Hudson, N., Ball, K., McNatty, K.P., Lun, S., Heath, D., Kieboom, L.E. \& McDiarmid, J. (1986) Use of bovine follicular fluid to increase ovulation rate or prevent ovulation in sheep. J. Reprod. Fert. 76, 623-635.

Henderson, K.M., McNatty, K.P., O'Keeffe, L.E., Lun, S., Heath, D.A. \& Prisk, M.D. (1987) Differences in gonadotrophin-stimulated cyclic AMP production by granulosa cells from Booroola $\times$ Merino ewes which were homozygous, heterozygous or noncarriers of a fecundity gene influencing their ovulation rate. J. Reprod. Fert. 81, 395-402.

Lindsell, C.E., Rajkumar, K., Manning, A.W., Emery, S.K., Mapletoft, R.J. \& Murphy, B.D. (1986) Variability in FSH:LH ratios among batches of commercially available gonadotrophins. Theriogenology 25, 167, Abstr.

McNatty, K.P., Gibb, M., Dobson, C., Thurley, D.C. \& Findlay, J.K. (1981) Changes in the concentrations of gonadotrophic and steroidal hormones in the antral fluid of ovarian follicles throughout the oestrous cycle of the sheep. Aust. J. biol. Sci. 34, 67-80.

McNatty, K.P., Hudson, N., Gibb, M., Ball, K., Henderson, K.M., Heath, D.A., Lun, S. \& Kieboom, L.E. (1985) FSH influences follicle viability, oestradiol biosynthesis and ovulation rate in Romney ewes. J. Reprod. Fert. 75, 121-131.
McNatty, K.P., Lun, S., Heath, D.A., Ball, K., Smith, P., Hudson, N.L., McDiarmid, J., Gibb, M. \& Henderson, K.M. (1986) Differences in ovarian activity between Booroola $\times$ Merino ewes which were homozygous, heterozygous and non-carriers of a major gene influencing their ovulation rate. $J$. Reprod. Fert. 77, 193-205.

McNatty, K.P., Hudson, N., Henderson, K.M., Gibb, M., Morrison, L., Ball, K. \& Smith, P. (1987) Differences in gonadotrophin concentrations and pituitary responsiveness to $\mathrm{GnRH}$ between Booroola ewes which were homozygous (FF), heterozygous $(\mathrm{F}+)$ and non-carriers $(++)$ of a major gene influencing their ovulation rate. $J$. Reprod. Fert. 80, 577-588.

McNeilly, A.S. (1985) Effect of changes in FSH induced by bovine follicular fluid and FSH infusion in the preovulatory phase on subsequent ovulation rate and corpus luteum function in the ewe. J. Reprod. Fert. 74, $661-668$.

Miller, K.F., Nordheim, E.V. \& Ginther, O.J. (1981) Periodic fluctuations in FSH concentrations during the ovine estrous cycle. Theriogenology 16, 669-679.

Monniaux, D., Chupin, D. \& Saumande, J. (1983) Superovulatory responses of cattle. Theriogenology 19, 55-81.

Wright, R.W., Bondioli, K., Grammer, J., Kuzan, F. \& Menino, A. (1981) FSH or FSH plus LH superovulation in ewes following estrus synchronization with medroxy progesterone acetate pessaries. J. Anim. Sci. $52,115-118$.

Zeleznik, A.J. \& Kubik, C.J. (1986) Ovarian responses in macaques to pulsatile infusion of follicle stimulating hormone (FSH) and luteinizing hormone: increased sensitivity of the maturing follicle to FSH. Endocrinology 119, 2025-2032.

Received 11 January 1988 